\title{
Orí (Head) as an Expression of Yorùbá Aesthetic Philosophy
}

\section{Olusegun Ajíbóyè}

\author{
Stephen Folárànmí \\ Nanashaitu Umoru-ọkẹ
}

Department of Fine and Applied Arts, Obafemi Awólọ́wọ University, Ile-Ife, Nigeria

Doi: $10.2478 / \mathrm{mjss}-2018-0115$

\begin{abstract}
Aesthetics was never a subject or a separate philosophy in the traditional philosophies of black Africa. This is however not a justification to conclude that it is nonexistent. Indeed, aesthetics is a day to day affair among Africans. There are criteria for aesthetic judgment among African societies which vary from one society to the other. The Yorùbá of Southwestern Nigeria are not different. This study sets out to examine how the Yorùbá make their aesthetic judgments and demonstrate their aesthetic philosophy in decorating their orí, which means head among the Yorùbá. The head receives special aesthetic attention because of its spiritual and biological importance. It is an expression of the practicalities of Yorùbá aesthetic values. Literature and field work has been of paramount aid to this study. The study uses photographs, works of art and visual illustrations to show the various ways the head is adorned and cared for among the Yoruba. It relied on Yoruba art and language as a tool of investigating the concept of ori and aesthetics. Yorùbá aesthetic values are practically demonstrable and deeply located in the Yorùbá societal, moral and ethical idealisms. It concludes that the spiritual importance of orí or its aesthetics has a connection which has been demonstratively established by the Yorùbá as epressed in the images and illustrations used in this paper.
\end{abstract}

Keywords: Yoruba aesthetic, Head, Hair style, Facial marks and Body decorations

\section{Introduction}

The discovery of African art first in the fifteenth century and again in the nineteenth century generated immense interest among the Eurocentric discoverers who found it unbelievable that highly sophisticated conceptual and realistic art could come from cultures they considered and judged primitive. Their reluctance to accept this sophistication drove contentious theories about external influences in African art. The originality of this art was proven by the appropriation of this art by early twentieth-century European painters. The influence of African art on European modern painting commenced with cubism, followed by other epochal artistic upheavals of the twentieth century notably the commencement of abstraction in modern European painting (Fleming, 1980).

According to Brain, (1980) African traditional art is predominantly and multi-variously functional, while Hackett, (1999) described it as art that is collectively used and owned by the society which exerts influence on it. The artist in the African traditional society was not just a stereotypical hand for his society and the gods; some degree of creativity that amount to individuality in style is recognized and identifiable by the society. This nullifies the earlier belief that anonymity was a defining character of the traditional art Africa (Willett, 2002). The traditional African 
artist did not work with utmost independence and individuality akin to that of the twentieth-century European artist involving in the creation of art's sake, but like any artist in any culture they work within the confinement of their society's norms, accepted symbols and conventions.

The societal influence on the artist cannot be overlooked; his influence and importance cannot also be ignored. At the service of the society the artist brings to "making of images, conceptions that have been instilled in them by their cultures" (Gardner, Tansey, \& De la Croix, 1986). Fleming, (1980) explains that "conventions of a period are the inherited, invented, and prescribed formulas that people who informed the culture generally understood." All these cultural norms, formulas, conventions and rules in an African environment inform the preference and ideals of beauty in traditional African artistic forms.

The preferences and ideals of beauty in traditional African art constitute the African aesthetics. The rules of aesthetics in some African societies are well laid out and comprehensive in some societies while in others they are less elaborate or just inferred. This paper therefore examines the concept of the head according to Yorùbá philosophical thoughts and how this is demonstrated in the aesthetics attached to it. Emphasis will be laid on the nature of traditional African aesthetics and how these aesthetic criteria are demonstrated on Yorùbá biological form; the head. Though, the search for what constitutes beauty or acceptable criteria for beauty ${ }^{1}$ has always being the concern of man since the beginning of art, aesthetics as an academic subject is a more recent development. A proper understanding of the subject is therefore necessary for proper comprehension of this endeavor.

\section{Research Methodology}

Our methodology employed the theory Yorùbá Art and Language where Abióndún (2014) suggests that "we look beyond what is curiously observed if we are to understand Yorùbá art." In essence he offers that "we should not be content with only formalistic analysis of Yorùbá art, but endeavor to understand it as an expression of the thought and belief system that produced it. Abióndún's statement is directly relevant to the method that we must use in the investigation of these images and Yoruba aesthetic philosophy (Folárànmí, 2018) ${ }^{2}$. Fifteen (15) images comprising photographs, sculptures and illustrations were purposively selected. These images were selected because they cut across the important aspects of Yoruba aesthetics as it relates to orí. These are head adornment such as plaiting or weaving of hair, facial markings, and head coverings such as caps and gèlè. The paper therefore examined the formal qualities of the images using relevant Yorùbá metaphors as suggested by Abióndún.

\section{What is Aesthetics?}

Aesthetics refers to the branch of philosophy that deals with issues of beauty and artistic taste. Borev, (1985:13) further defines aesthetics as a philosophical branch that deals with the "historically determined essence of human values, their creation, perception, appreciation and assimilation." African aesthetic on the other hand though mostly unwritten are handed down orally and contained in their common sayings and proverbs. For instance the Yorùbá say "funfun ni iyi eyín," - the beauty of the teeth lies in its whiteness" and "kó gún régé ni iyì ọrùn," - "straightness is the beauty of a good neck," shows that the Yorùbá have philosophies concerning the appreciation of beauty. Generally, African aesthetics favor stylization and abstraction in various degrees. Credence is, nonetheless, given by the Yorùbá traditional shrine murals ${ }^{3}$ which are abstracted to high degrees.

\subsection{African Traditional Aesthetics as a Focus}

Even though the study of aesthetics had gone on in Europe for centuries, Africans have developed

\footnotetext{
${ }^{1}$ Beauty has always been the essence of aesthetics

2 This is Our Story: Iconography of Carved Doors and Panels in Ọyọ́ Palace African Arts 51 (2):44-57 (in press)

${ }^{3}$ See (Campbell, 2001; S. Folárànmí, 2002; Okediji, 1989)
} 
preferences and criteria for determining acceptable works or qualifying and assessing art. This area has received only little academic attention. Researchers' normally did not turn to African aesthetics until much later after the 'discovery' of African art. Till the 1980s there was little literature in this area compared to other scholarly studies on African art. Willett, (2002) gives a brief review of works focused on African aesthetics and concludes that works in this area are few. He identified and reviewed limited researches and experiments done by Himmelheber, (1935); Vandenhoute, (1948) and Fernandez, (1966) on some African groups. Himmelheber, (1935, 1972) was the first researcher on African aesthetics with the study of the artists of the Guro and Atutu while Vandenhoute, (1948) studied and conducted experiments on the Dan of Ivory Coast. His work revealed that the following; symmetry of the vertical axis, balance, rhythm, harmony between forms or masses, technical finishing and function (ergonomics of use by the wearer of the mask) are the principles guiding them in their sculptures, though they do not have words or specialized terminologies for it $(1948,210-211)$.

Fischer \& Himmelheber, (1984) studied the Dan of North Eastern Liberia and established that interpretative abstraction is required and not "photography" while Fernandez's research on the Fang of Gabon reveals that technical qualities (finishing-well done and smooth), balance (of all features on both sides of the body of figural sculpture) and frontality are the desirable qualities (Fernandez, 1966:210-220).

Research on the Yorùbá of Southwestern Nigeria by Thompson, (1971) is probably one of the first elaborate efforts at deriving the aesthetic qualities among any African group or the Yorùbá in particular. According to Thompson, the following criteria; jijora - resemblances', ifarahàn establishment of features, dídán - finished, gígún - symmetry, and tútù - coolness are considered judgments on works of art. These qualities agree with the ones identified by Lawal, (1974:14; 1993). Abiodun, (1986) also reveals similar aesthetic criteria and locates same in the Yorùbá societal moralistic framework and ideal moral ethics of the individual. Brain, (1980:264) studied the Kalabari ${ }^{4}$ of South-South Nigeria, revealing that criticism of works of art is not based on "ugliness" or beauty in achieving perfection of form but on symbolic function. Aesthetic judgment is based on "factors involving the correctness of symbols used and the traditional style and resemblance to certain natural features" (Brain, 1980, 264). This functional quality is similar to the Bwami society of the Balega whose traditional sculptures have been studied (Willett, 2002:21).

Vansina, (1984:130-132) critiqued earlier researches on African aesthetics, complaining that their methodology of data collection led to information that was speculative, rated with European standards, and limited in scope to only Africa. The study was however not all criticism, some insights into African aesthetics are revealed; African art works were first appreciated for their emotional appeal at least by the general public. For instance, a Cameroon (Bangwa) mask was seen as terrifyingly ${ }^{5}$ beautiful because it elicited fear from the public as required by the secret society that used it, therefore appeal of a work of art depends on function and use, meaning and place in social context. Furthermore, aesthetic requirements vary according to cultural differences e.g., north Africa's preferences stuck to lines, arabesques, mathematical elegance of lines in light and shadow and prismatic use of color to accentuate lines and shapes because of their sociocultural contexts, while Africa favored sensual volumes and solids, the angular and elliptical. Some also prefer shiny polished finishing and decorations, while some prefer the natural state of the media.

In conclusion, Vansina states that styles are not indicators of the character or temperament of any culture but that if the links "between beauty and the tenor of culture" are to be explored, "they must expressly be found probably through the analysis of "aesthetic criteria" and their link to "ethnical criteria." That "ethical criteria" can be located in the Yorùbá community. (Abiodun, n.d.)1330).

\footnotetext{
${ }^{4}$ The Kalabari Kingdom, is a historic town in Morse Rivers State, Southern part of Nigeria. The Kingdom was founded by the great Amachree I, forefather of the Amachree dynasty, which is now headed by the Princewill family.

${ }_{5}^{5}$ 'Terrifyingly beautiful' as against 'grotesque that is usually used for such works (see Egonwa, 2017).
} 


\subsection{Yorùbá Aesthetic Concepts}

One of the most comprehensive researches on Yorùbá's traditional aesthetic philosophy is that of Abiodun, (1983:13-30) which situates aesthetics in the deep linguistic, cultural and metaphysical contexts of the Yorùbá of southern Nigeria. The aesthetic sensibilities of the Yorùbá is drawn from experience, but properly imparted by moving or interacting with the elders, the custodians of knowledge and experience. Proper manifestation of aesthetically pleasing expression is based on the awareness and possession of certain aesthetic qualities which are found in iwà, human behavior. Abióndún defines the concept of beauty, ewà as related to iwà, human character and proves that the most required criteria and ability to recognize ewà (beauty) are all contained in the positive entity, ìwàpè̀eé, coolness of behavior (Abiodun, 1990:60-70).

According to Abiodun, (1990:78) the following attributes are the components of iwàpèlé (coolness) that must be imbued on the critic and artists in order to be relevant and functional at aesthetic levels. Ojú inú - inner eye, is an insight that allows the artist to see beyond the physical appearance and application of the elements of design and be able to apply them to suit the occasion and desired function. Ojú inú is therefore an acquired attribute that is derivable only through cultural experience and interaction with the elders. Ojú inú - further means "design consciousness" that is a talent that can also be learnt or acquired through training by those who possess it.

In Yorùbá, proverbs, sayings, stories, and culture provide guidelines to direct the artist's expressive designs. Ojú inú directs the artist on appropriateness to context in the use of innovations. Ifarabalè - literally translates to "calming or controlling the body," or letting reason rather than emotion control man 'or' not losing one's composure (Abiodun, 1990:77). It entails the artist's ability to control himself mentally and technically and have enough restful temperament to see a work through to its success. Dídán which means "completeness" or "finishing" is a consequence of İarabalè. Ilutí - which means literally "good hearing." It idiomatically refers to qualities such as 'teachableness', obedience, and understanding which are highly required in the "traditional, educational and apprenticeship systems of the Yorùbá" (Abiodun, 1990:78). The deeper meanings of ilútí refer to efficacy and responsive abilities to purpose. Therefore, in Yorùbá art criticism, ilútí refers to the fulfillment of artistic intentions and precision of execution. lilútí is a vital requirement for the critic and audience to execute, understand and enjoy the artwork and its messages.

Imójú mọ́ra is another factor that comes into importance in the adoption of new styles, techniques and materials and also a factor that explains the survival of the Yorùbá culture in new environments and against aggressive imposing cultures. This however does not imply that the Yorùbá culture is abhorrent to change and innovations. Imójú móra only curtails excesses and ensures reasonableness. Another important factor is tító which according to Abiọ́dún means "enduring" "unfading qualities" and "reality," as well as "genuineness" and "steadfastness." Tító enshrines durability of artistic material and style and discourages transient innovations, fads and ephemeral beauty (Abiodun, 1990:81).

Abiodun's criteria appear synonymous to Thompson's (earlier mentioned) because they were based on field work that included many respondents. But while Thompson's work covered just about two hundred (200) Yorùbá informants, Abiodun's field work which took about four years and rests on an insider's command of Yorùbá language. Hence, Thompson's account was more focused on technical implications of the principles of style and finishing as well as form, Abiódún, by contrast, further exploited his long and deep knowledge of the culture to uncover the connection of aesthetic principles with character, dwelling richly on Yorùbá metaphysics, and oral literature ${ }^{6}$.

\section{Yorùbá Concept of Orí, Head}

To Yorùbá generally, the head is regarded as the most important part of the body because it houses the most essential parts that coordinate human activities-the eyes, ears, mouth and nose.

\footnotetext{
${ }^{6}$ See also (Abiodun, 2014)
} 
The head is regarded as the seat of wisdom, hence in most African images, the head is usually depicted larger in size compared to the body, and no definite ratio is required. The Yorùbá of western Nigeria and the Diaspora divide the head into two; the physical head ori ita, and the spiritual head orí-inú. It is the physical head that houses the spiritual head. The importance of ori cannot be overemphasized, apart from the beauty, ewà, of the physical head ori ita, they also believe that the beauty (aesthetic value) of the spiritual head ori inú is greater. There are sayings that buttress this: "orí là bá bọo ká fi òrișà silẹ" - the head is worthy to be placated rather than the gods or goddesses. "ori ẹni ni àwúre" - "one's head is ones affluence." These sayings portray the importance of the head and the justification for its embellishments among the Yorùbá who believe that if an individual's ori is well taken care of, it will definitely bring material success. According to Yorùbá philosophical thought, the inner head is regarded as a spiritual essence that contains the whole destiny of man on earth, hence it is represented bigger than the rest of the body in Yorùbá traditional sculpture (Abiodun, 1986, 1987) and (Aremu, 2000).

\subsection{Yorùbá Aesthetic Expression in Orí, Head}

The expression of aesthetics among the Yorùbá covers many artistic forms. These includes expressions that come in sculpture, wall painting, pottery, textile (woven or dyed) and body art. It also includes architecture such as houses, public places, palaces and shrines ${ }^{7}$. It appears that the first and most immediate medium of expression is the body. The Yorùbá takes embellishment as part of the general grooming of the body which includes cleaning it. Yorùbá body adornments can be grouped under two headings; the primary adornments and secondary adornments. Primary adornments are aesthetic decorations done directly on the body using the body as the main medium while other implements or devices are used to manipulate it into forms of designs. Examples of these are hair weaving, facial markings, tattoos and all types of scarifications on the skin. Secondary adornments within the context of this paper refers to decorations, or art attached to the body to make it look more beautiful or aesthetically pleasing. Headgears, clothing, beads and jewelry and the major aspects of secondary adornments. The focus here shall be on the aesthetic decorations applied to ori-head only.

\subsection{Primary Adornments}

Orí (head) as discussed earlier is divided into ori inú, the spiritual head and "orí ita, the physical head $^{8}$. The Yorùbá attaches spiritual importance to the physical head as representation of the inner head and therefore it should be kept in the best aesthetic state. Generally, the hair is rarely left without adornment and a considerable time is spent to make it aesthetically appealing.

The Yorùbá male is expected to shave his head clean or keep the hair as low as possible and this is considered aesthetically pleasing. Cleanliness is considered a high virtue in body and environmental aesthetics. A bushy male hair is condemned and deridingly referred to as irun kikún bii ìộfà àjoyá, meaning literally "a head that is bushy like that of a slave that serves everybody and no one is ready to take responsibility for his upkeep." His serving everybody left him with no time to shave his head. An exclusive style of hair cut is the one in which half of the head is shaved running from the front to the back while one side is left with hair. This is usually the style worn by the Ilar ${ }^{9}{ }^{9}$ in ancient times. No other person is allowed to wear this type of hair style. In Yorùbá religious circles, the unique relationship between Șàngó and women according to Olomo, (2009:317) also makes it almost mandatory for male devotees to braid their hair and sometimes dress as women in order to attain status and approach the divine force that Saangó is called (Fig. 1). That should however not be confused with modern trends in contemporary Africa and the African Diaspora where boys and men braid or weave their hair for aesthetic and other reasons (Fig. 2).

\footnotetext{
${ }^{7}$ See (Dmochowski, 1990; Amole \& Folaranmi, 2017)

${ }^{8}$ See (Lawal, 1985)

${ }^{9}$ illàri refers to a court messenger in the palace of the Aláäin of Òyọ. The title of the names by which they are called usually emanates from the duties they perform for the Oba.
} 


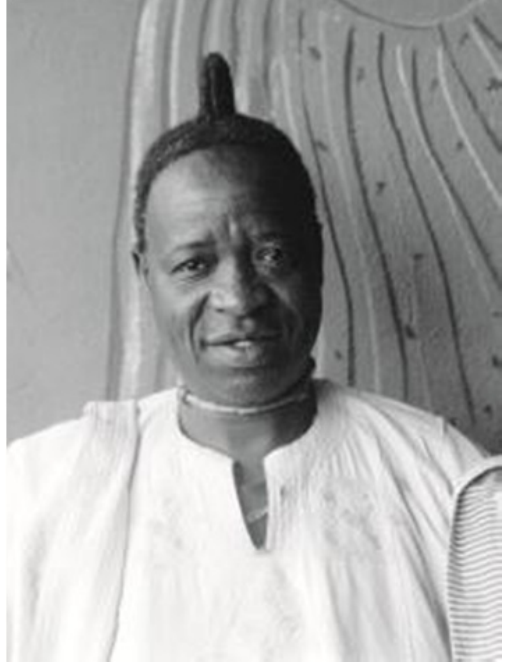

Figure 1. Sango devotee. Photograph by Uli Beier, 1960 (Institute of Cultural Studies Obafemi Awólọ́wọ University, lle-Ife

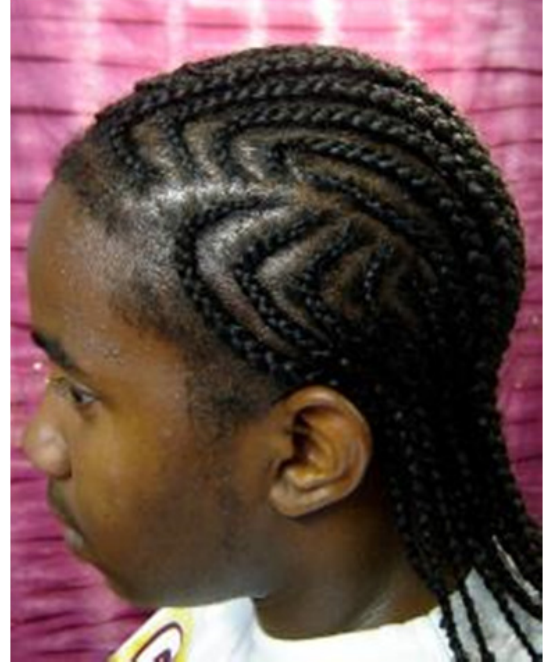

Figure 2. Contemporary hair plaiting among men in the twentieth and twenty first century. Courtesy. www.hairbraidingstyles.org

The Yorùbá female hair is more elaborately treated than the male hair and in it can be seen the creativity of the Yorùbá in hair decoration. The female hair is left to grow and decorated by weaving and threading it into different coiffeurs which are identifiable by generally recognized names. Compared to weaving, threading is considered recent. Both manners of hair decoration are considered as household knowledge handed down from generation to generation among women. One of the most common hair weaving style is șùkú which cuts the hair into woven strands stuck to the head and running from the base of the head to the center, ending in a small protrusion (Fig. 3). The șùkú hair style is sometimes considered royal. Certain hairstyles are reserved for royal-hood and are not to be done on any commoner's head (Fakeye, Haight, Curl, \& Gallery, 1996). Other Yorùbá weaving styles are korobá, kòlẹ́sè̀, panumọ́ eléègé, ọkọ ńlọ- ọkọ ń bò, ipàkọ́ ẹlẹ́dẹ e.t.c. (Figs. 4, 5, 6, 7). Yorùbá hair weaving are practical applications of ojú ọnà, design consciousness and ojú inú, inner eyes which is particularly required at the starting points of weaving.

At the early stage of lila irun - 'dividing the hair into design formations' that the foundation for the final ewà, beauty is laid. Ojú inú, inner eye stipulates the right manners of dividing the hair of the particular head to achieve an overall beauty. Ifarabalè, calm and control is then required to carry out the weaving process in such a careful manner that allows for proper execution of the design.

The face is another decorated part of the head. The commonest facial decoration is the facial marks which are usually administered on the male and female at birth. They are carried out with sharp knives locally designed for the purpose by professionals known as olóolà. The markings which are in lines (short or long, ones, twos or several in different combinations and various manners) are meant to serve two functions; identity and aesthetics. The beauty of pélé, a type of Yorùbá facial marks is expressed in the praise, "pélé yẹ 'jú, meaning "pélé befits the eye." It is often a praise name for ladies with befitting pélé. Groups or lineages often have their peculiar identities, for example, the Òndó have their facial marks as two markings on either cheeks that look like the number eleven. There are different types of facial marks and many are common and have names by which they are known. Just as the șùkú is commonly found on many female figures in Yorùbá carved wood, so also are facial marks found on gẹlẹe masks from the region (Lawal, 1996:23637). 
The art of cutting Yorùbá facial marks ${ }^{10}$ requires a high skill with an abundance of ojú inú, inner eye to determine precision in cutting so that it does not become ugly when the child becomes an adult. A lot of ifarabalè, calmness is therefore required to be able to cut without harming the child. Imójú mọ́ra, curtailment of excesses keeps the olóòlà from absorbing disrupting artistic innovations that may alter the facial marks; this will not be welcomed since the facial marks are expected to be group identities. Imójú mọ́ra ensures the constant and unvarying skill of the olóòà as the custodian of the societal facial logo.

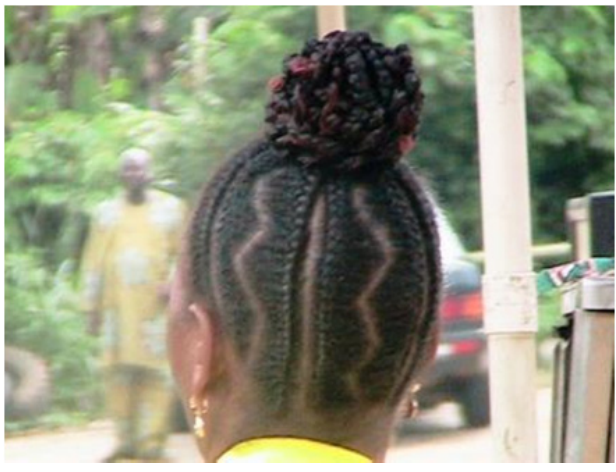

Figure 3. Yoruba woman with sùkú hair style. Photograph by Stephen Fọlárànmí, November, 2007.

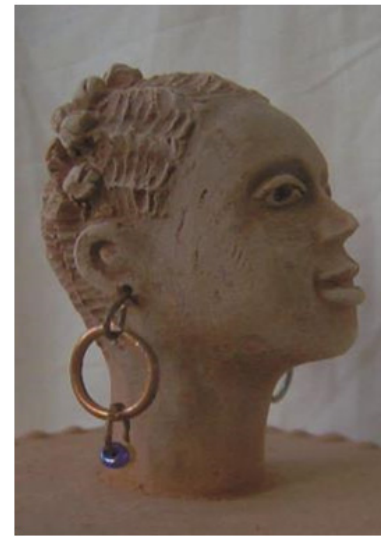

Figure 5. Sculpture showing kòlésè hairstyle by Ségun Ajíbóyè, terracotta, 2005.

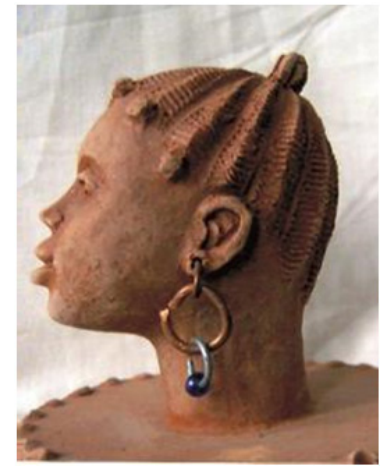

Figure 4. Sculpture showing sùkú hairstyle. Ségun Ajíbóyè, terracotta, 2005.

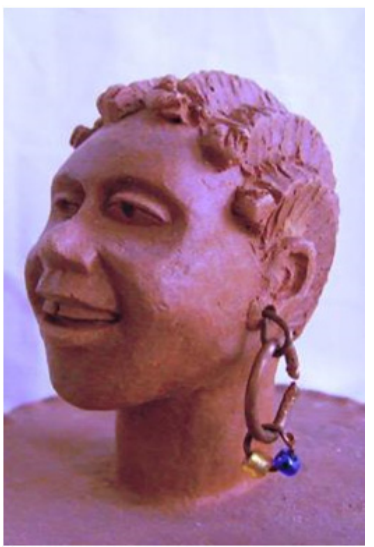

Figure 6. Sculpture showing panumó hairstyle by Ségun Ajíbóyè, terracotta, 2005.

Some of the commonly identified ones are àbàjà, àbàjà merin, àbàjà alágbélé, pélé, túrè, kẹkẹ or gọmbọ́, àbàjà Olówu, kẹ́kẹ Olówu, ilà Òndó, àbàjà Ėgbá, àbàjà İjèsà, àbàjà Ékitì. Some examples of these are found in figure 8, 9, 10 and 11. It is pertinent to mention that certain markings on some Yorùbá faces are therapeutic and not for identification or aesthetics. One such mark is the short mark under the lower lip; it is usually administered with concoction rubbed in so that the child does

${ }^{10}$ The basic and common Yorùbá facial marks can be found in (Johnson, 1976:104-110); (Daramola \& Jeje, 1967) (1975) and on the Gẹ̀lẹdẹ masks in (Lawal, 1996a) 
not experience teething problems.

The eye, ojú is very important to the Yorùbá as imọ́lè ara, the light of the body. The ability to see inwards and outwards as well as spiritually is well recognized by the Yorùbá when they qualify the eye as ojú inú, inner eye and ojú ita, outer eye. Aremu, (2000:49) further emphasizes the importance of ojú, eye as a spiritual entity and an aesthetic requirement for the Yorùbá carver to accomplish his aesthetic role. The eye is not only important to the artist but also to the critic or public who must also possess ojú inú that can only be acquired by cultural interaction and education (Abiodun, 1990:75). In visual contacts among humans, the eye is usually the focus and it creates instant and lasting impressions. The Yorùbá at all times prefer their eyes to look good so as to elicit ojú rere, favorable disposition. One of the many ways to make the eyes more pleasing by the Yorùbá is by the use of a type of local eye pencil known as tiróò.

Tiróo is a local eye pencil consisting of lead grounded into fine powder and poured into a small metal container of about two inches that looks like a miniature beaker. The mouth is a long pipe of about an inch long with a small broom stick that touches the base on the metal container when inserted. To use the tiróo, the broom stick is pulled out gently and the stained end (with lead) is applied to the eye lids the way a modern eye liner is used. The aesthetic results are the eyes that look like those of Queen Nefertiti of ancient Egypt. Applying tiróo to the eyes is done with a lot of carefulness and skill that requires ifarabalè, calmness so as to be able to apply accurately. Tiróo is essentially a female affair but some tiróo are believed to have some herbal medicines added to them to imbue them with curative capabilities in the treatment of the eye. It is also believed that this type of tiróo helps in achieving clarity of vision. For this reason some men apply tiróo to their eyes. However, for some respondents, the use of tiróo attributed some metaphysical uses of tiróo especially when used by the male. It is generally believed that men use tiróo mainly for good therapeutic and metaphysical reasons.

\subsection{Secondary Adornments}

Secondary adornment for orí, head in the case of Yorùbá women is gèlè, head gear and filà, cap for the men. Men's filà range from filà ode - hunter's cap (Fig. 12) to filà abetí ajá, the cap with ears like a dog (Fig. 13) and many others. There are different variations of caps with different designs and traditional motifs achieved with embroidery which can be hand or machine embroidered (Fig. 14). The Yorùbá do not consider it a good or complete dress mode when the cap is missing, so also the gèlè in the case of a woman.

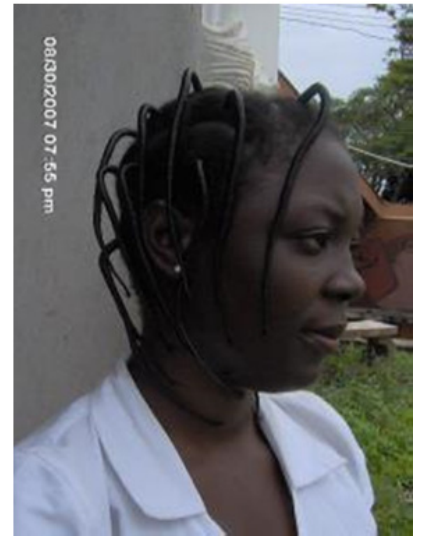

Figure 7. Irun Kíkó. Hairstyle usually achieved by using rubber or cotton thread wound around the hair. Photograph by Stephen Fọlárànmí, 2007

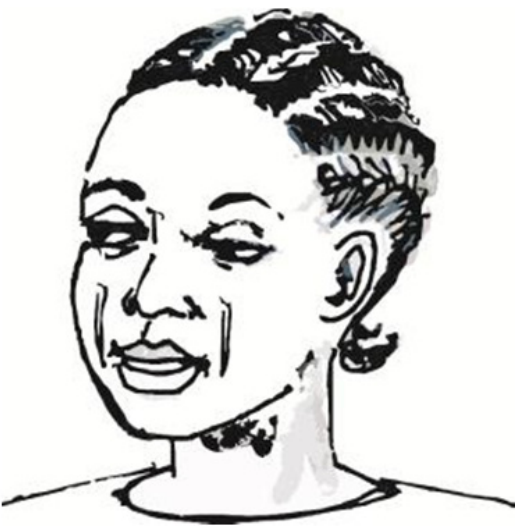

Figure 8. Girl with facial marks of the Òndó people. Illustration by Ségun Ajíbóyè, 2010. 

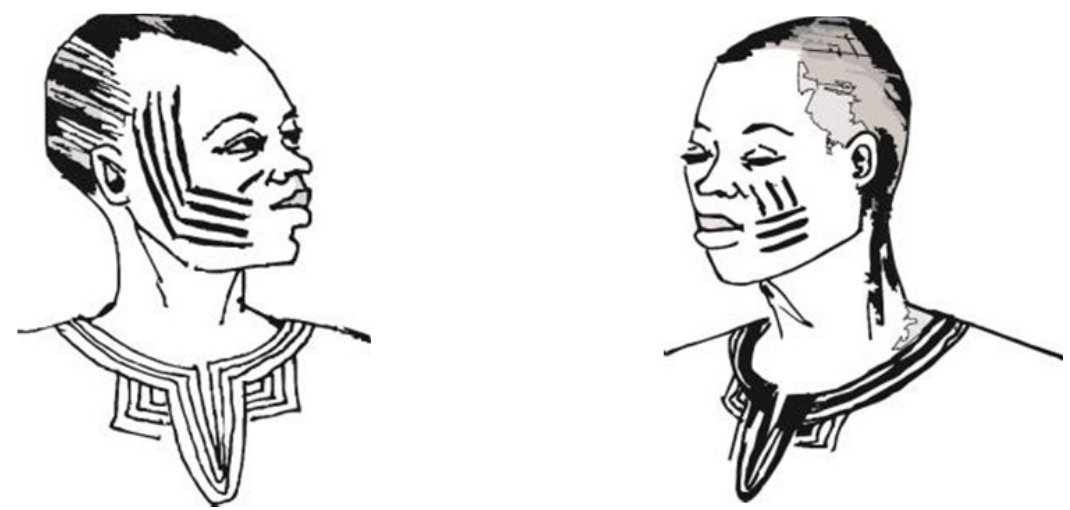

Figure 9. Man with Gombo facial marks. Figure 10. Man with Abaja Olowu. Illustration by Ségun Ajíbóyè, 2010. Illustration by Ségun Ajíbóyè, 2010.

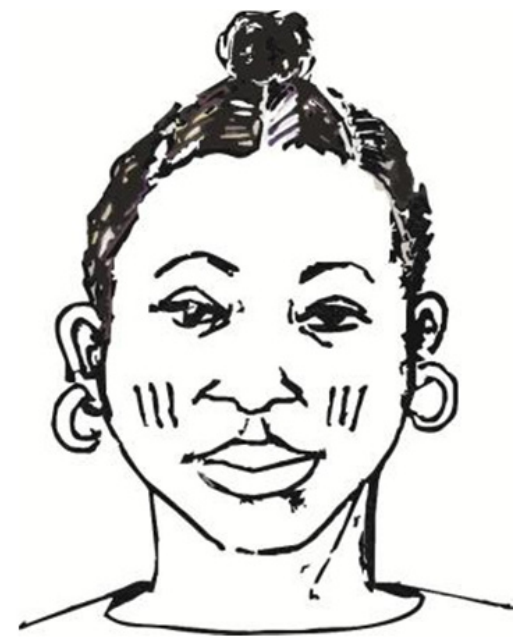

Figure 11. Lady showing Pélé. Illustration by Ségun Ajíbóyè, 2010.

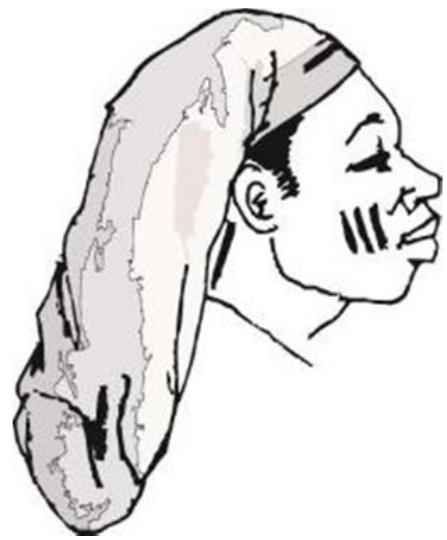

Figure 11. Man with Pélé adorning Fila Ode. Illustration by Stephen Fọlárànmí, 2011 
In modern times, the Yorùbá filà, cap has become an element of personal identity. Many Yorùbá political leaders and influential personages have come to be recognized with particular caps. An example is the round-base short cap now referred to as 'Awo cap' which was popularized by late Chief Ọbáfémi Awólọ́wọ, a leading Yorùbá political leader. There are other well-known Yorùbá political leaders who have identified themselves with various caps designs. Notable are the former governor of Òsun State, Late Alhaji Isiaka Adeleke, whose cap is popularly called sèrùbàwón, Senator Bola Tinubu and Alhaji Lateef Jakande, both former governors of Lagos State, Otunba Iyiola Omisore a former Senator of the Federal Republic of Nigeria and late Alagba Adebayo Faleti, renowned author, playwright and actor. The Aláàfin of Ọyọ, Ọba Lamidi Adéyemí when not adorning his crown has become known particularly with the Yorùbá cap known as abetí ajá (Fig. 13).

As earlier stated, Imójú mọ́ra, curtailment of excesses is a controlling factor which ensures that designs appropriated for identity and symbolism does not lose its constancy, as the case of the Yorùbá facial marks. It appears that this aesthetic attribute is possessed by some of the Yorùbá leaders who have identified themselves with certain filà, caps. Imójú mọ́ra has kept them to stick to a type of cap constantly to the extent that they became known with it, despite the availability of other equally beautiful and attractive types. Apart from individual identities, social, ethnic, professional and interest groups commonly identify with themselves by wearing identical caps made from the same material ranging from asọ-òkè, ànkárá and damask.

For Yorùbá women, it is the gèlè (headgear) (Fig. 14 and 15), that has the most dynamism and artistic qualities among the ladies. It is often learnt just like hair weaving is done. It however requires greatly, personal creativity to achieve the various aesthetic appearances. Gèlè goes through series of folding and drapery control that requires a lot of deep ojú inú, inner eye to determine the final shape aimed at and how to achieve it while ojú onà, creativity is needed for the creative idea. Each gèlè is inevitably subject to all the possibilities of spontaneous innovations by not coming out in the same shape even when a previous shape is aimed at. Maneuverability of the gèlè is a gradually acquired skill which starts from early age among ladies. However, some respondents disclosed that sometimes, the skill comes naturally as a gift to some women without any deliberate early training.

Gèlè is sourced from the material used for the iró and bùbá for the female and filà is made from the same textile material for bùbá and șòkòtò or agbádá for the man. The woven textiles of the Yorùbá were well developed and supplied quality materials and designs which were rated higher than imported ones from Manchester (Atanda, 1980:26). This was in addition to the local dyeing industry which produced àdirẹ ẹlẹkọ (tie and dye) and àdìre ẹlẹkọ (dyed material with local cassava starch).

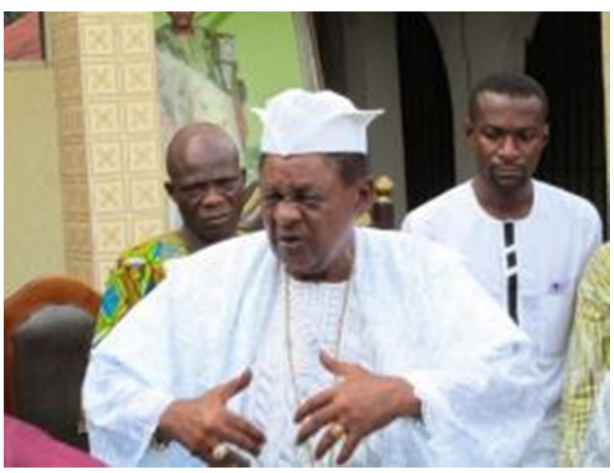

Figure 13. Aláàfin of Oyo, Oba Lamidi Adéyẹmí adorning his famous abetí ajá cap. Photograph by Stephen Fọlárànmí, 2013

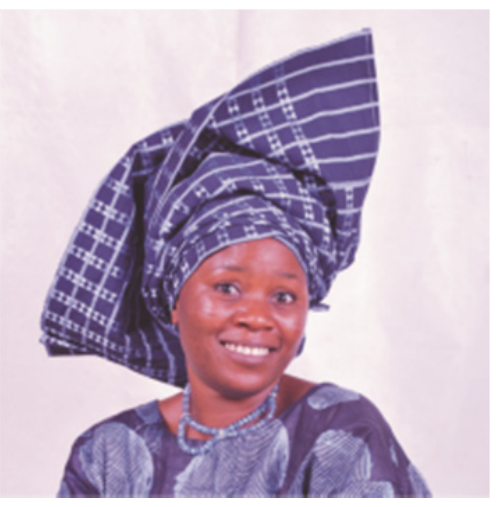

Figure 14. Lady with Yoruba Gèlè made out of asọ-òkè. Photograph by Stephen Fọlárànmí, 2011 


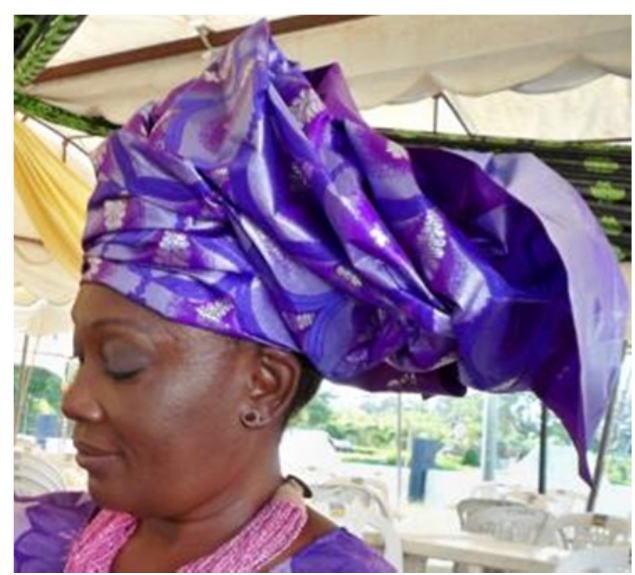

Figure 15. Woman with Yoruba Gèlè made out of damask material. Photograph by Mojúbàolú Okome, 2008

\section{Conclusion}

Spiritual importance of ori or its aesthetics has a connection which has been demonstratively established by the Yorùbá. The spiritual and physical importance of ori among the Yorùbá has provided a locus for the expression of traditional aesthetics. Yorùbá traditional aesthetics are not just theories or philosophies but practically demonstrable aesthetic tenets in their day to day affairs. The practical expression of the traditional Yorùbá aesthetics not only validates their philosophy but makes judgment possible. The moralistic nature and intents of this philosophy becomes even more relevant in contemporary Nigerian art as traces of it can be seen in traditional modern Yorùbá sculpture.

\section{References}

Abiodun, R. (n.d.). Identity and the Artistic Process in the Yoruba Aesthetic Concept of Iwa. Journal of Cultures and ldeas, 1, 13-30.

Abiodun, R. (1986). Verbal and visual metaphors : mythical allusions in Yoruba ritualistic art of ori. Ife : Annals of the Institute of Cultural Studies, University of Ife, Nigeria., (1), 8-39.

Abiodun, R. (1987). Verbal and visual metaphors: mythical allusions in Y aruba ritualistic art of Orí. Word \& Image. https://doi.org/10.1080/02666286.1987.10435384

Abiodun, R. (1990). African art studies : the state of the discipline : papers presented at a symposium organized by the National Museum of African Art, Smithsonian Institution, September 16, 1987. Washington, D.C.: National Museum of African Art.

Abiodun, R. (2014). Yoruba Art and Language: Seeking the African in African Art. New York: Cambridge University Press.

Amole, B., \& Folaranmi, S. (2017). Architecture: Indigenous. In T. Falola \& A. Akinyemi (Eds.), Culture and Customs of the Yoruba (pp. 171-189). Austin, Texas: Pan-African University Press.

Aremu, P. S. O. (2000). Spirituality in Yorùbá wood Decorated Carvings. Journal of Arts and ldeas, 2(3), 44-54.

Atanda, J. A. (1980). An introduction to Yoruba history. Ibadan, Nigeria: Ibadan University Press.

Borev, Y. (1985). Aesthetics : a textbook. Moscow: Progress Publishers.

Brain, R. (1980). Art and society in Africa. London: Longman.

Campbell, B. (2001). Yoruba shrine painting traditions : color, cosmos, process and aesthetics.

Daramola, O., \& Jeje, A. (1967). Awon Asa ati Orisa ile Yoruba. Ibadan: Onibonoje Press.

Dmochowski, Z. (1990). An Introduction to Nigerian Traditional Architecture: South West and Central Nigeria (Volume 2). Lagos: The National Commission for Museums and Monuments.

Egonwa, D. O. (2017). African Art: A contemporary Source Book. Lagos: Egonsay Publishers. 
Fakeye, L. O., Haight, B. M., Curl, D., \& Gallery., D. P. A. C. \&. (1996). Lamidi Olonade Fakeye : a retrospective exhibition and autobiography. Holland, Mich.: Hope College.

Fernandez, J. W. (1966). Principles of Opposition and Vitality in Fang Aesthetic. Journal of Aesthetics and Arts Criticism, 25(1), 53-64.

Fischer, E., \& Himmelheber, H. (1984). The arts of the Dan in West Africa. Zurich: Museum Rietberg.

Fleming, W. (1980). Arts \& ideas. New York: American library colour slide Co.

Folárànmí, S. (2002). The Importance of Oríkì In Yoruba Mural Art. ljele, Art E-Journal of the African World, 4(2). Retrieved from http://www. africaknowledgeproject.org/index.php/ijele/rt/metadata/905/0

Folárànmí, S. A. (2018). This Is Our Story: Iconography of Carved Doors and Panels in Òyọ́. African Arts, 51(2), 44-57.

Gardner, H., Tansey, R. G., \& De la Croix, H. (1986). Gardner's art through the ages, volume 1: ancient, Medieval, and non-European art. San Diego, CA: Harcourt Brace Jovanovich, Publishers.

Hackett, R. I. J. (1999). Art and Religion in Africa. London and New York: Casell.

Himmelheber, H. (1935). Negerkunstler: ethnographische Studien Uber den Schnitzkunstler bei den Stummen der Atutu und Guro im Innern der Elfenbeinkuste : (Ergebnisse einer Forschungsexpedition). Strecker und Schroder, Stuttgart.

Himmelheber, H. (1972). Masken, Tanzer und Musiker der Elfenbeinkuste. Gottingen: Institut fur den Wissenschaftlichen Film.

Johnson, S. (1976). The History of the Yoruba. Lagos: CSS.

Lawal, B. (1974). Some aspects of Yoruba aesthetics. London: British journal of aesthetics.

Lawal, B. (1985). Orí: The Significance of the Head in Yoruba Sculpture. Journal of Anthropological Research, 41(1), 91-103. Retrieved from http://www.jstor.org/stable/3630272

Lawal, B. (1993). Some Aspects of Yoruba Aesthetics. In R. L. Anderson \& K. L. Field (Eds.), Art in small-scale societies: contemporary readings (p. 452). Prentice-Hall.

Lawal, B. (1996a). The Gelede spectacle: art, gender, and social harmony in an African culture. Seattle: University of Washington Press.

Lawal, B. (1996b). The Gẹ̀lẹdé Spectacle: Art, Gender, and Social Harmony in an African Culture. Seattle University of Washington Press, xxiv, 327.

Okediji, M. (1989). Orisaikire painting school in Ile-Ife. Kurio Africana : Journal of Art and Criticism., 1, 116-129.

Olomo, A. (2009). Sango Beyond Male and Female. In J. E. Tishken, T. Falola, \& A. Akinyemi (Eds.), Sàngó in Africa and the African Diaspora (p. 311-322.). Bloomington: Indiana University Press.

Sanga, I. (2017). Antinomies of African aesthetics and the impulses of aesthetic relativism: reading p'Bitek, Abiodun and Agawu. African Identities. https://doi.org/10.1080/14725843.2017.1291327

Thompson, R. F. (1971). Esthetics in traditional Africa. Art and Aesthetics in Primitive Societies., 374-381.

Vandenhoute, P. J. L. (1948). Classification stylistique du masque Dan et Guere de la Cote d'Ivoire occidentale (XVI). Leiden: Mededelingen van het Rijksmuseum voor Volkenkunde.

Vansina, J. (1984). Art History in Africa: An Introduction to Method. London Longman Group Limited.

Willett, F. (2002). African art. London: Thames \& Hudson. 